\title{
CHEMICAL EVALUATION OF HEPATIC FUNCTION IN NIGERIANS
}

\author{
BY \\ J. C. EDOZIEN \\ From the Department of Chemical Pathology, University College, Ibadan, Nigeria
}

(RECEIVED FOR PUBLICATION APRIL 19, 1958)

Most of the tests of liver function normally performed in a routine laboratory depend on quantitative and qualitative changes in the serum proteins. Since it is now well established that the serum protein pattern in Africans differs significantly from that generally accepted as normal for Europeans (Arens and Brock, 1954; Edozien, 1957 ; Holmes, Stanier, Semambo, and Jones, 1951; Schofield, 1957), it appeared of some importance to investigate the results of these routine tests when applied to healthy Nigerians. Such an investigation would not only provide normal values for the local population but may throw further light on the mechanism of the turbidity and flocculation tests of hepatic function.

\section{Materials}

Fasting blood samples were collected from 200 healthy adult Nigerians (160 males and 40 females) between the ages of 15 and 40 years. The sera were separated as soon as possible after collection (one to two hours to allow for clot retraction). Most of the analyses were performed on the same day on which the samples were collected, but occasionally when it was not possible to complete the analyses the specimens were stored in the refrigerator at $4^{\circ} \mathrm{C}$., and the investigations completed the following morning.

Analyses were undertaken on each sample of bilirubin (total and direct reacting), alkaline phosphatase, proteins, thymol turbidity and flocculation, zinc sulphate turbidity, cephalin cholesterol flocculation, and colloidal gold flocculation.

Cholesterol (total and ester) was estimated and zone electrophoresis on paper for proteins and lipoproteins was also performed; the detailed consideration of this latter group of analyses will be presented elsewhere.

A bromsulphthalein excretion test was also done on 50 of the fasting subjects.

The serum of 50 Europeans resident in Ibadan, 25 cases of infective hepatitis, and 25 cases of hepatic cirrhosis were also examined by the same methods.

\section{Methods}

Bilirubin.-The method of Powell (1944) was used. As the final dilution of the serum was 1 to 10 , the buffered methyl red standard of King and Coxon (1950) was employed as standard. Direct bilirubin was read at 10 minutes.

Alkaline Phosphatase.-This was estimated by the method of King and Wootton (1956).

Total Proteins.-The biuret method of Wolfson, Cohn, Calvary, and Ichiba (1948) was chosen.

Paper Electrophoresis.-The method of Flynn and de Mayo (1951) was used. Approximately $0.3 \mathrm{mg}$. serum proteins $/ \mathrm{cm}$. Whatman No. 1 filter paper, i.e., 0.2 to $0.25 \mathrm{ml}$. serum on a $5 \mathrm{~cm}$. wide paper, was applied. Electrophoresis was for 18 hours at 120 volts. The papers were dried for $30 \mathrm{~min}$. at $105^{\circ} \mathrm{C}$., then stained for 10 minutes in $0.75 \%$ azocarmine B (Gurr) in 50\% methanol $+10 \%$ glacial acetic acid and finally washed in successive changes of $10 \%$ acetic acid until a clear background was obtained. After drying at $105^{\circ} \mathrm{C}$. for 15 minutes the papers were oiled with Shandon clearing oil and scanned in an Eel transmission densitometer. Quantitative estimations were made with an Ott compensating planimeter. A globulin correction coefficient of 1.6 was applied. This factor was derived from electrophoresis as described above of a solution containing known quantities of pure albumin and pure $\gamma$ globulin prepared by continuous paper electrophoresis of pooled human serum. The same coefficient was applied to all the globulin fractions.

Thymol Turbidity and Flocculation.-The estimation was made according to the method of Maclagan (1944, 1947a, 1947b) and Neefe (1946). Two tubes were prepared for each serum, one used to read the turbidity, the other for the flocculation which was read after 18 hours.

Zinc Sulphate Turbidity.-Kunkel's (1947) method was used. Both the thymol and the zinc sulphate turbidities were read after 30 minutes in a "unicam" 

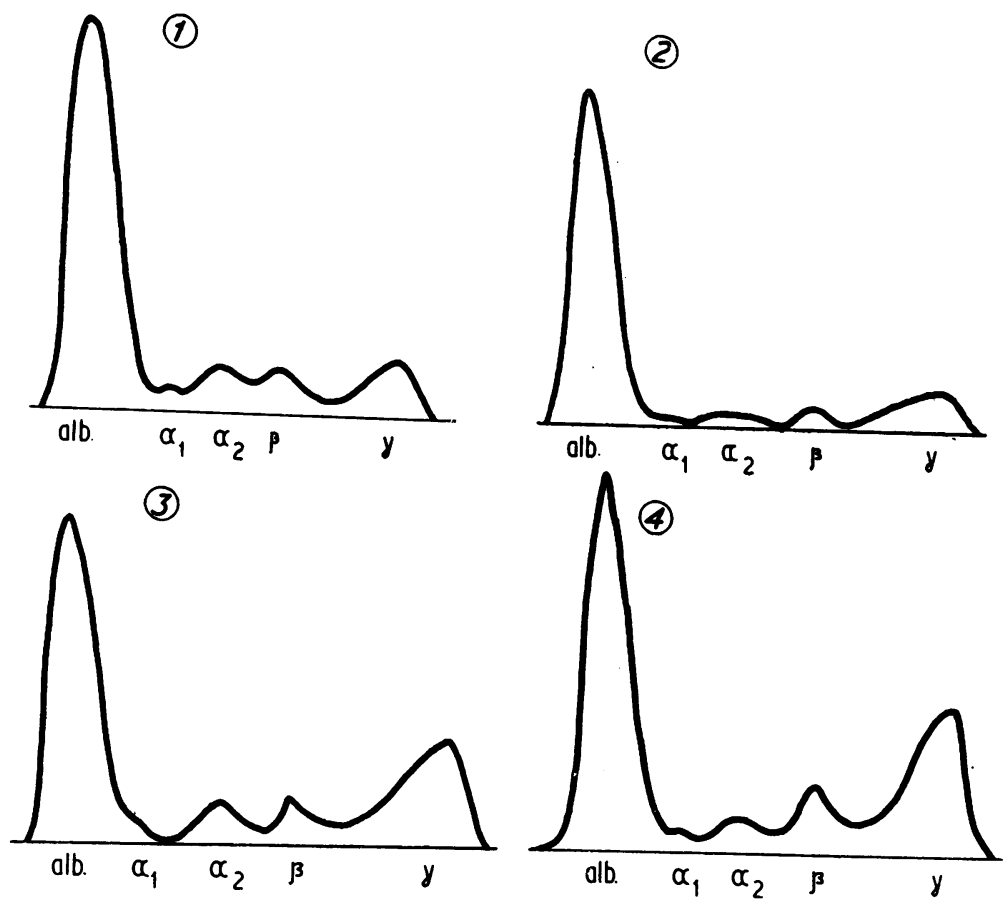

FIG.1.-Results of electrophoresis. (1)

Typical European pattern; (2)

Nigerian with low globulin level, $<1.5 \mathrm{~g} . / 100 \mathrm{ml}$. (about $5 \%$ of those examined); $(3,4)$ typical Nigerian patterns; $(5,6)$ " cirrhosis" of liver in Nigerians.
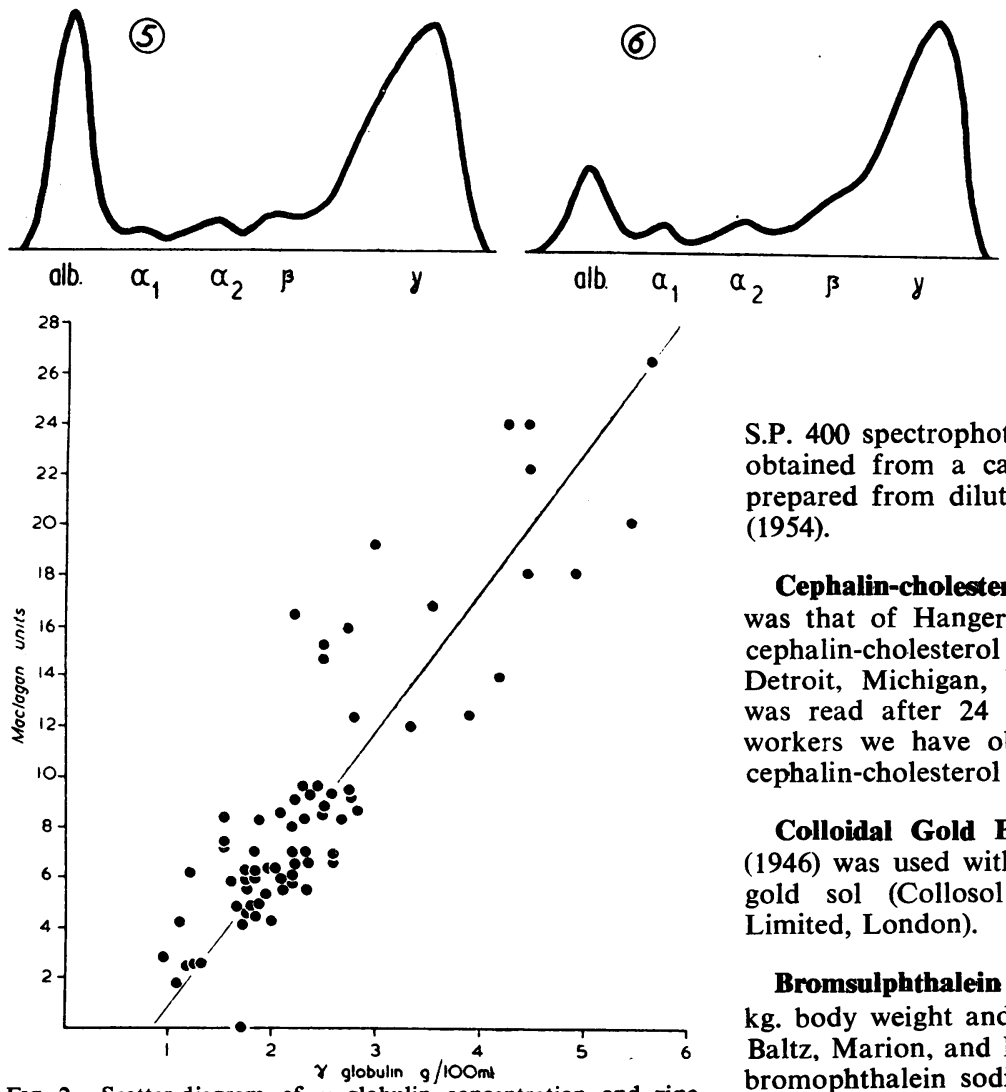

FIo. 2.-Scatter diagram of $\gamma$ globulin concentration and zinc sulphate turbidity readings.

S.P. 400 spectrophotometer at $660 \mathrm{~m} \mu$ and the values obtained from a calibration curve. The curve was prepared from diluted serum as described by Varley (1954).

Cephalin-cholesterol Flocculation.-The method was that of Hanger (1939). Commercially obtained cephalin-cholesterol antigen (Difco Laboratories, Detroit, Michigan, U.S.A.) was used. Flocculation was read after 24 hours in the dark. Like other workers we have observed that different batches of cephalin-cholesterol antigen vary greatly in sensitivity.

Colloidal Gold Flocculation.-Maclagan's method (1946) was used with commercially obtained colloidal gold sol (Collosol Aurum, Crookes Laboratories Limited, London).

Bromsulphthalein Test.-This was based on $5 \mathrm{mg}$./ kg. body weight and the method was that of Mateer, Baltz, Marion, and MacMillan (1943). Sterile sulphobromophthalein sodium (Savory \& Moore Ltd., London) was employed. 


\section{Results}

The results are presented in Tables I, II, III, and IV and in Figs. 1 and 2.

TABLE I

RESULTS OF ANALYSIS ON 200 NIGERIANS

\begin{tabular}{|c|c|c|}
\hline Determination & Range & Average \\
\hline 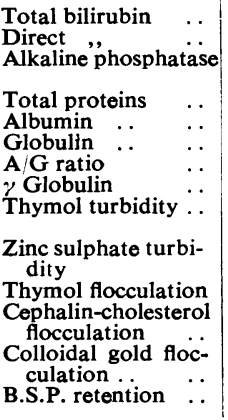 & 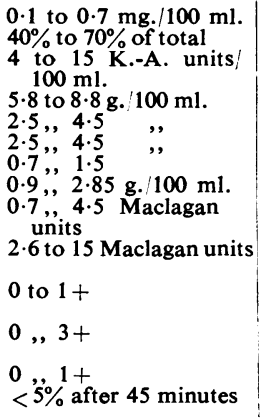 & $\begin{array}{l}6.95 \pm 0.4 \mathrm{~g} . / 100 \mathrm{ml} \\
3 \cdot 50 \pm 0.3 \quad, \\
3.45 \pm 0.45 \quad, \\
1.01 \\
2.05 \pm 0.35 \mathrm{~g} . / 100 \mathrm{ml} . \\
2 \cdot 10 \pm 0.25 \text { Maclagan } \\
\text { units } \\
7.0 \pm 1 \cdot 5 \quad \text { Maclagan } \\
\text { units }\end{array}$ \\
\hline
\end{tabular}

TABLE II

RESULTS IN ADULT NIGERIANS AND EUROPEANS LIVING IN IBADAN

\begin{tabular}{|c|c|c|}
\hline & 200 Nigerians (g. $/ 100 \mathrm{ml}$ ) & 50 Europeans (g. $/ 100 \mathrm{ml})$. \\
\hline  & $\begin{array}{l}6.95 \pm 0.40(5.8 \text { to } 8.80) \\
3.50 \pm 0.31(2.5,, 4.50) \\
0.20 \pm 0.03(0.09,, 0.50) \\
0.51 \pm 0.09(0.30,, 0.80) \\
0.69 \pm 0.15(0.30,, 1.00) \\
2.05 \pm 0.35(0.90,, 2.85) \\
3.45 \pm 0.45(2.50,, 4.50) \\
1.014 \pm 0.18(0.70,, 1.50)\end{array}$ & $\begin{array}{l}6.92 \pm 0.53(6.00 \text { to } 8.50) \\
4.05 \pm 0.30(3.50,, 5.00) \\
0.32 \pm 0.03(0.21,, 0.60) \\
0.52 \pm 0.05(0.23,, 0.80) \\
0.83 \pm 0.12(0.51,, 1.10) \\
1.20 \pm 0.21(0.50,, 1.60) \\
2.87 \pm 0.31(2.00,, 4.00) \\
1.411 \pm 0.21(0.80,, 1.90)\end{array}$ \\
\hline
\end{tabular}

TABLE III

THYMOL AND ZINC SULPHATE TURBIDITIES IN HEALTH AND IN LIVER DISEASE

\begin{tabular}{|c|c|c|c|c|}
\hline \multirow{2}{*}{ Subject } & \multicolumn{2}{|c|}{ Thymol Turbidity } & \multicolumn{2}{|c|}{ Zinc Sulphate Turbidity } \\
\hline & Range & Average & Range & Average \\
\hline $\begin{array}{l}200 \text { Nigerians } \\
50 \text { Europeans } \\
25 \text { infective } \\
\text { hepatitis } \\
25 \text { hepatic } \\
\text { cirrhosis .. }\end{array}$ & $\begin{array}{l}0.7 \text { to } 4.5 \\
0.5,, 4.0 \\
6.0,, 15.0 \\
4.4,, 10.7\end{array}$ & $\begin{array}{l}2 \cdot 1 \pm 0.25 \\
1.9 \pm 0.40 \\
8 \cdot 3 \\
6.9\end{array}$ & $\begin{array}{r}2.6 \text { to } 15.0 \\
0.5,, 7.0 \\
9.8,, 22.0 \\
12.0,, 22.5\end{array}$ & $\begin{array}{l}7 \cdot 0 \pm 1 \cdot 5 \\
3 \cdot 6 \pm 0 \cdot 9 \\
16 \cdot 3 \\
18 \cdot 1\end{array}$ \\
\hline
\end{tabular}

Results expressed in Maclagan units.

\section{Discussion}

The serum bilirubin, alkaline phosphatase, and bromsulphthalein retention test give in Nigerians results which are not significantly different from those in Europeans. The serum protein pattern and some of the turbidity and flocculation tests, however, give results which by European "norms" would be considered pathological.

The protein pattern differs in that the serum of Africans contains less albumin and more $\gamma$
TABLE IV

FLOCCULATION TESTS IN HEALTH AND DISEASE

\begin{tabular}{|c|c|c|c|c|c|c|c|c|c|c|c|c|}
\hline \multirow[b]{2}{*}{$\begin{array}{l}\stackrel{\mathscr{N}}{3} \\
\stackrel{3}{3}\end{array}$} & \multicolumn{4}{|c|}{$\begin{array}{c}\text { Thymol } \\
\text { Flocculation }\end{array}$} & \multicolumn{4}{|c|}{$\begin{array}{l}\text { Cephalin- } \\
\text { cholesterol } \\
\text { Flocculation }\end{array}$} & \multicolumn{4}{|c|}{$\begin{array}{l}\text { Colloidal } \\
\text { Gold } \\
\text { Flocculation }\end{array}$} \\
\hline &  & 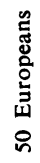 & 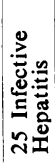 &  & 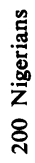 & 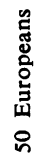 & 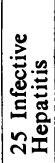 &  & 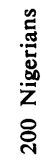 & 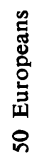 & 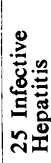 &  \\
\hline $\begin{array}{l}0 \\
1+ \\
2+ \\
3+ \\
4+ \\
5+\end{array}$ & $\begin{array}{r}185 \\
14 \\
1 \\
0 \\
0 \\
-\end{array}$ & $\begin{array}{r}47 \\
3 \\
0 \\
0 \\
0 \\
\end{array}$ & $\begin{array}{r}0 \\
0 \\
11 \\
10 \\
4 \\
-\end{array}$ & $\begin{array}{r}1 \\
0 \\
8 \\
12 \\
4 \\
\end{array}$ & $\begin{array}{r}37 \\
95 \\
58 \\
10 \\
0 \\
-\end{array}$ & $\begin{array}{r}38 \\
10 \\
2 \\
0 \\
0 \\
\end{array}$ & $\begin{array}{r}0 \\
0 \\
6 \\
8 \\
11 \\
\end{array}$ & $\begin{array}{r}0 \\
0 \\
3 \\
10 \\
12 \\
\end{array}$ & $\begin{array}{r}173 \\
34 \\
3 \\
0 \\
0 \\
0\end{array}$ & $\begin{array}{r}46 \\
3 \\
1 \\
0 \\
0 \\
0\end{array}$ & $\begin{array}{l}0 \\
0 \\
2 \\
7 \\
8 \\
8\end{array}$ & $\begin{array}{r}0 \\
0 \\
1 \\
6 \\
13 \\
5\end{array}$ \\
\hline
\end{tabular}

globulin than the serum of Europeans (Fig. 1 and Table II), thus giving lower values for the $A / G$ ratio. The causes of this difference have been the subject of considerable discussion during the last few years. Holmes et al. (1951) have suggested that it is related to protein deficiency in the diet, and that the picture can be altered by feeding a high-protein diet. This finding is not in agreement with our observations in Nigerians. Arens and Brock (1954) believe that in Cape Town Africans it is caused by liver damage due to prolonged protein malnutrition, and that in other Africans from areas of endemic tropical disease it is accentuated by chronic parasitic infection. Schofield (1957) considers that it is the result of a pathological process in the liver caused by malarial infection.

The present investigation clearly shows, however, that the high $\gamma$ globulin levels in Africans are not a result of chronic hepatocellular damage because those tests of hepatic function which may be regarded as fairly specific for liver damagethymol turbidity, thymol flocculation, and bromsulphthalein excretion (Maclagan, 1948; Mateer et al., 1943, - do not show any abnormality in healthy Africans even though they have a high serum $\gamma$ globulin level. It also demonstrates that in hepatitis and cirrhosis in Africans there is a further increase in serum $\gamma$ globulin (Fig. 1) and that the protein flocculation tests show pathological changes similar to those associated with liver disease in Europeans (Tables III and IV).

The most likely explanation seems to be that these differences have a true genetic origin (Edozien, 1957). This view is supported by the finding that a significant difference exists between the zinc sulphate turbidity reading of healthy Negroes and whites in America (Reinhold, 1955). Vera and Roche (1956), working in Caracas, 
Venezuela, where malarial infestation is at present a rarity, have also observed that the average $\gamma$ globulin value in Negroes was higher than in the groups of whites and mestizos (varying mixture of races) who were studied. This work, however, needs confirmation in view of the small numbers of subjects examined. Studies on Nigerians of mixed race are at present in progress. It is possible that residence in the African environment may accentuate this racial characteristic by stimulating an increase in circulating antibodies, but it is important to recognize the fact that the $\gamma$ globulin in the serum of healthy Africans is normal $\gamma$ globulin unrelated to hepatic disease.

With regard to the protein flocculation tests, it is evident from Tables I, III, and IV that the thymol turbidity and flocculation and the colloidal gold flocculation tests show no significant differences between healthy Nigerians and Europeans. On the other hand many Nigerians present "abnormal" results with the zinc sulphate turbidity and cephalin-cholesterol flocculation. It is clear, therefore, that the increase in normal $\gamma$ globulin or the decrease in normal albumin which is observed in most Africans affects the results of the zinc sulphate turbidity and the cephalincholesterol flocculation, but does not disturb the thymol turbidity and flocculation and the colloidal gold flocculation. Qualitative changes in albumin and/or $\gamma$ globulin associated with hepatic disease are reflected in all the tests, including the thymol turbidity and flocculation.

Fig. 2 shows a scatter diagram of the $\gamma$ globulin values and the zinc sulphate turbidity readings. The results confirm the finding of others (Kunkel, 1947 ; Discombe, Jones, and Winstanley, 1954) that the zinc sulphate turbidity reflects quantitative changes in serum $\gamma$ globulin better than the other turbidity and flocculation tests. They also show that correlation between the two is much better with normal sera having $\gamma$ globulin concentrations less than $3.0 \mathrm{~g} . / 100 \mathrm{ml}$. than with abnormal sera showing higher concentrations of $\gamma$ globulin.

It is therefore recommended that the best combination of protein flocculation tests for the assessment of hepatic function in Africans consists of thymol turbidity, thymol flocculation, and colloidal gold flocculation. With this combination of tests healthy Africans with or without a high level of serum $\gamma$ globulin can readily be distinguished from those who have suffered hepatic cell damage. The general impression which has been created that most Africans go through life with damaged livers is unfounded and is undoubtedly due to improper choice of liver function tests. Most investigators in this field have relied on evidence based on $\mathrm{A} / \mathrm{G}$ ratio, $\gamma$ globulin estimation, zinc sulphate turbidity, Takata-Ara flocculation, and such other tests which are not sufficiently specific.

\section{Summary}

Bilirubin (total and direct reacting), alkaline phosphatase, proteins, thymol turbidity and flocculation, zinc sulphate turbidity, cephalincholesterol flocculation and colloidal gold flocculation have been estimated in the serum of 200 healthy adult Nigerians, 50 healthy adult Europeans resident in Ibadan, 25 cases of infective hepatitis, and 25 cases of hepatic cirrhosis.

Evidence is produced to show that the high $\gamma$ globulin level in the serum of Africans is not due to hepatic cell damage.

It is recommended that the best combination of protein flocculation tests for the assessment of hepatic function in Africans consists of thymol turbidity, thymol flocculation, and colloidal gold flocculation. With this combination of tests healthy Africans with or without a high level of serum $\gamma$ globulin can readily be distinguished from those who have suffered hepatic cell damage.

I wish to express my thanks to Mr. D. Simmonds and Mr. F. Speed, of the Medical Illustration Unit, University College, Ibadan, for the illustrations, and to Professor P. Collard for reading the manuscripts and offering valuable criticism.

\section{REFERENCES}

Arens, L., and Brock, J. F. (1954). S. Afr. J. clin. Sci., 5, 20. Discombe, G., Jones, R. F., and Winstanley, D. P. (1954). J. clin. Path., 7, 106.

Edozien, J. C. (1957). Ibid., 10, 276.

Flynn, F. V., and Mayo, P. de (1951). Lancet, 2, 235.

Hanger, F. M. (1939). J. clin. Invest., 18, 261.

Holmes, E. G., Stanier, M. W., Semambo, Y. B., and Jones, E. R. (1951). Trans, roy. Soc. trop. Med. Hyg., 45, 371.

King, E. J., and Coxon R. V. (1950). J. clin. Path., 3, 248.

Wootton, I. D. (1956). Micro-Analysis in Medical Biochemistry, 3rd ed., p. 83. J. \& A. Churchill, London.

Kunkel, H. G. (1947). Proc. Soc. exp. Biol. (N.Y.), 66, 217.

Maclagan, N. F. (1944). Brit. J. exp. Path., 25, 15. (1946). Ibid., 27, 369.

(1947a). Brit. med. J., 2, 197.

- (1947b). Biochem. J., 41, xxxvii.

- (1948). Brit. med. J., 2, 892.

Mateer, J. G., Baltz, J. I., Marion, D. F., and MacMillan, J. M. (1943). J. Amer. med. Ass., 121, 723.

Neefe, J. R. (1946). Gastroenterology, 7, 1.

Powell, W. N. (1944). Amer. J. clin. Path., 14, 55.

Reinhold, J. G. (1955). Clin. Chem., 1, 351.

Schofield, F. D. (1957). Trans. roy. Soc. trop. Med. Hyg., 51, 332.

Varley, H. (1954). Practical Clinical Biochemistry, 1st ed., p. 463. William Heinemann, London.

Vera, J., and Roche, M. (1956). J. Lab. clin. Med., 47, 418.

Wolfson, W. Q., Cohn, C., Calvary, E., and Ichiba, F. (1948). Amer. J. clin. Path., 18, 723. 